\title{
Implementasi Kurikulum dan Strategi Pembelajaran Pendidikan Agama Islam pada PAUD
}

\author{
Zulfa \\ SekolahTinggi Agama Islam Negeri (STAIN) Salatiga \\ e-mail: zulfa.stains3@gmail.com
}

\begin{abstract}
Abstrak
Kurikulum merupakan bagian integral dari pendidikan. Kurikulum juga merupakan media untuk menumbuhkan nilai-nilai agama pada anakanak, terutama di bidang pendidikan anak usia dini (usia 0-6 tahun). Fokus utama dari penelitian ini adalah beberapa Pendidikan Anak Usia Dini (PAUD) di Kota Salatiga dan Kabupaten Semarang. Penelitian ini bertujuan untuk memperoleh suatu tujuan, faktual, akurat dan sistematis proses pelaksanaan kurikulum pendidikan Islam dan strategi yang diterapkan pada objek penelitian. Data dikumpulkan dengan beberapa metode yaitu observasi, dokumentasi dan wawancara. Kemudian data yang dikumpulkan dianalisis dengan menggunakan pendekatan deskriptif kualitatif. Hasil penelitian menunjukkan pelaksanaan kurikulum pendidikan agama Islam di PAUD di Salatiga dan kabupaten Semarang sudah mengacu pada standar di Permendiknas Nomor 58 tahun 2009. Beberapa dari mereka belum mengacu patokan dasar pemerintah. Mereka juga melakukan pengembangan yang sesuai dengan karakteristik masingmasing lembaga. Bahan pendidikan agama Islam yang diberikan cocok dengan tahap perkembangan peserta didik. Materi tersebut disampaikan melalui bercerita, bercakap-cakap, tugas, Iqro ', simulasi dan praktek.
\end{abstract}

Curriculum is an integral part of education. The curriculum is also a medium to cultivate of religious values in children,especially in early childhood education (ages 0-6 years). The main focus of this study is some early childhood education in Salatiga and Semarang district. This 
study is aimed to gain an objective, factual, accurate and systematic of curriculum implementation process of Islamic education and its strategies that applied in the research object. The data is collected by several methods namely, observation, documentation and interviews. Then the gathered data were analyzed using descriptive qualitative approach. The results indicate the implementation of Islamic religious education curriculum in early childhood education in Salatiga and Semarang districts already refers to the standards in Permendiknas No. 58 of 2009. Some of them have not referring to the government's basic benchmark. They also undertake the development which is appropriate with the characteristics of each institution. The materials of Islamic religious education is given suited with stage of learners' development. It is delivered by storytelling, chatting, assignments, Iqro ', simulation and practice.

Kata kunci: implementasi, kurikulum pendidikan Islam, strategi

\section{Pendahuluan}

Pendidikan merupakan tanggung jawab bersama antar keluarga, sekolah, dan masyarakat, bahkan menjadi tanggung jawab seluruh bangsa Indonesia. Awal pendidikan itu di mulai sejak anak usia dini atau sejak lahir karena Pendidikan Usia Dini (PAUD) pada dasarnya berpusat pada kebutuhan anak, yaitu pendidikan yang berdasarkan pada minat, kebutuhan, dan kemampuan sang anak. Oleh karena itu, peran pendidik sangatlah penting. Dan pendidik harus mampu memfasilitasi aktivitas anak dengan material yang beragam.

Dalam Undang-Undang Sistem PendidikanNasional Pasal 1 angka 14 menyatakan bahwa pendidikan anak usia dini adalah "suatu upaya pembinaan yang ditujukan kepada anak sejak lahir sampai dengan usia enam tahun yang dilakukan melalui pemberian rangsangan 
pendidikan untuk membantu pertumbuhan dan perkembangan jasmani dan rohani agar anak memiliki kesiapan dalam memasuki pendidikan lebih lanjut”.(UU Sisdiknas,2003: 4)

Berdasarkan tingkat pertumbuhan dan perkembangannya, pendidikan di mulai sejak anak usia dini yang terbagi ke dalam 3 tahapan. Untuk kelompok usia selanjutnya, pengelompokan dilakukan dalam rentang waktu per tahun (Permendiknas No 58 tahun 2009:2).Tahap usia $0-<2$ tahun, terdiri atas kelompok usia: (a) kurangdari 3 bulan, (b) 3 sampaidengan 6 bulan, (c) 6 sampaidengan 9 bulan, (d) 9 sampaidengan 12 bulan, (e) 12 sampaidengan 18 bulan, dan (f) 18 sampaidengan 24 bulan. Tahap usia 2 sampaidengan 4 tahun terdiri atas kelompok usia2 sampaidengan3 tahundan $\quad 3$ sampaidengan 4 tahun. AdapunTahap usia 4 sampaidengan 6 tahun terdiri atas kelompok usia4 sampaidengan 5 tahun5 sampaidengan6 tahun.

Pendidikan Agama Islam (PAI) yang diberikansejak dini dapat membantu perkembangan anak terutama dalam hal pembentukankarakter, sikap dan tingkah laku. Hal inidikarenakanPAI merupakan segala usaha yang berupa pengajaran, bimbingan dan asuhan terhadap anak agar kelak setelah pendidikannya dapat memahami, menghayati dan mengamalkan ajaran-ajaran agamaislam serta menjadikannya sebagai way of life (jalan kehidupan) sehari - hari, baik dalam kehidupan pribadi maupun sosial kemasyarakatan.

Urgensi pendidikan Islam dapat dilihat dari pengertian pendidikan Islam itu sendiri. Dalam UU SPN No. 2/1989 pasal 39 ayat 2 ditegaskan bahwa isi kurikulum disetiap jenis, jalur jenjang serta pendidikan wajib 
memuat pendidikan agama. Pendidikan agama merupakan usaha utuk memperkuat iman dan ketaqwaan terhadap Tuhan yang Maha Esa sesuai dengan agama yang dianutnya dengan memperhatikan tuntutan pengembangan karakter generasi bangsa serta untuk menghormati agama lain dalam hubungan kerukunan antar umat beragama dalam masyarakat untuk mewujudkan persatuan nasional.

Usia dini merupakan masa emas dalam tahap perkembangan manusia dan merupakan jenjang pendidikan sebelum jenjang pendidikan dasar yang merupakan suatu upaya pembinaan yang ditujukan bagi anak sejak lahir sampai dengan usia enam tahun yang dilakukan melalui pemberian rangsangan pendidikan untuk membantu pertumbuhan dan perkembangan jasmani dan rohani agar anak memiliki kesiapan dalam memasuki pendidikan lebih lanjut, yang diselenggarakan pada jalur formal, nonformal, dan informal. Dan menurut penelitian para ahli bahwa fungsi otak manusia terkait dengan tingkat kecerdasannya, sehingga optimalisasi kecerdasan dimungkinkan sejak usia dini dengan stimulasi yang tepat untuk perkembangan otaknya.( Mansur, 2009: 97)

Dengan diberlakukannya UU No. 20 Tahun 2003 maka sistem pendidikan di Indonesia terdiri dari PAUD, pendidikan dasar, pendidikan menengah, dan pendidikan tinggi yang keseluruhannya merupakan kesatuan yang sistemik. PAUD diselenggarakan sebelum jenjang pendidikan dasar. PAUD dapat diselenggarakan melalui jalur pendidikan formal, nonformal, dan/atau informal. PAUD pada jalur pendidikan formal berbentuk Taman Kanak-kanak (TK), Raudatul Athfal (RA), atau bentuk lain yang sederajat. PAUD pada jalur pendidikan nonformal 
berbentuk Kelompok Bermain (KB), Taman Penitipan Anak (TPA), atau bentuk lain yang sederajat seperti Satuan PAUD Sejenis (SPS) yang meliputi PAUD TPQ, Pos PAUD. PAUD pada jalur pendidikan informal berbentuk pendidikan keluarga atau pendidikan yang diselenggarakan oleh lingkungan.

Dijelaskan dalam Petunjuk Teknis Penyelenggaraan Taman Kanak-Kanak, (Kemendiknas, 2011:27) bahwa Program Pembelajaran di Taman Kanak-Kanak mencakup bidang pengembangan perilaku dan pengembangan kemampuan dasar yang terdiri atas pengembangan aspekaspek sebagai berikut:a) Moral dan nilai-nilai agama, b) Sosial, emosi, c) Bahasa, d) Kognitif, e) Fisik/Motorik, f) Seni.

Maka untuk menumbuh-kembangkan aspek-aspek tersebut diperlukan cara-cara tertentu yang sesuai dengan kebutuhan anak usia dini. Pada umur ini, kepribadiannya mulai terbentuk dan ia sangat peka terhadap tindakan-tindakan orang di sekelilingnya. PAI di PAUD tidak ada standar kurikulum baku dari kementerian terkait. Para pengelola PAUD mendesain sedemikan rupa kurikulum PAI yang sesuai dengan kondisi sekolah untuk kemudian diimplementasikan dengan metode pembelajaran. Hal ini tidak lepas dari semakin diminatinya PAUD yang bercirikan keislaman, baik dari segi nama, kurikulum bahkan seragam. Berdasarkan fenomena tersebut penting untuk diteliti tentang bagaimana implementasi Pelaksanaan Kurikulum dan strategi Pendidikan Agama Islam di PAUD Kota Salatiga.

Berdasarkan latar belakang masalah di atas, Untuk mempermudah pembahasan pada penelitian, maka permasalahan di rumuskan 
menjadidua, yaitu (1) Bagaimana Implementasi kurikulum Pendidikan Agama Islam di PAUD se kota Salatiga?, (2) Bagaimana strategi dan metode yang diterapkan dalam pembelajaran Pendidikan Agama Islam di PAUD kota Salatiga?

\section{MetodePenelitian}

Penelitian ini merupakan suatu penelitian deskriptif kualitatif, dalam pelaksanaanya pendekatan ini dipilih sebagai prosedur penelitian yang menghasilkan data diskriptif berupa kata-kata tertulis atau lisan dari orang-orang dan perilaku yang dapat diamati. (Moleong, 2002: 3) Dalam pelaksanaanya menekankan pada penggunaan teknik observasi, pengamatan terlibat (participant observation) yang meliputi kegiatan pembelajaran Agama di PAUD, strategi dan metode dalam pelaksanaanya.SelainituWawancara mendalam (indepth-interview) digunakandalam pengumpulan dataserta Teknik participant observationdandokumentasi/documentasi research digunakan untuk memperoleh gambaran detil kondisi PAUD di Kota Salatiga dan masyarakatnya.

Pada pelaksanaanya, penelitian ini dilaksanakan di PAUD Kota Salatiga danKabupaten Semarang yang diambil sesuai dengan jangkauan peneliti.Dibawah ini beberapa identitas lembaga yang penulis ambil sebagai sampel penelitian, antara lain:

\section{Nama PAUD}

Alamat

Salatiga

\section{: KB/RA Al Murtadzo}

: Jl. KH. Abdul Hamid I Pungkursari 


\section{Nama PAUD}

Alamat

Soka Salatiga

3. Nama PAUD

Alamat

4. Nama PAUD

Alamat

Salatiga

5. Nama PAUD

Alamat

Sidomukti,Salatiga.

6. Nama PAUD

Alamat

Salatiga

7. Nama PAUD

Alamat sekolah

8. Nama PAUD

Alamat

Salatiga

9. Nama PAUD

Alamat

Nanggulan Salatiga

10. Nama PAUD

Alamat

11. Nama PAUD

\section{: Al Qudwah Kids Center}

: Jl. KH Ahmad Dahlan RT 09 RW 07

: TK Islam Terpadu Al- Fitroh

: Jln.Perengrejo No 5 Gendongan Salatiga

: RA Yaa Bunayya

: Jl.Dliko Indah Gang 17 Blotongan

: RA Al Falah

$\begin{array}{llllll}\text { : JL. Janoko } 24 & \text { RT. } & 01 / & 02\end{array}$

: RA Ma'arif Kecandran

: Jl. Kyai Condro Kecandran Sidomukti

: KB dan RA Masyitoh

: Jln. Ja'far Sodiq No. 16 Kalibening

: TK 'Aisyiyah Pembina

: Jl.lmu. Adi Sucipto No.10 Kalicacing

: TK Aisyiyah 3

$\begin{array}{llll}\text { : Jl. Tanggulangu RT.03 RW.13 } & \text { R }\end{array}$

: TK Aisyiyah Bustanul Athfal

: Jl. Dliko Indah G.XIII, Sidorejo, Salatiga

: TK Hikmah Tazkia 
Alamat

Salatiga

12. Nama PAUD

Alamat

13. Nama PAUD

Alamat

14. Nama PAUD

Alamat

Salatiga

15. Nama PAUD

Alamat sekolah

16. Nama PAUD

Alamat

17. Nama PAUD

Alamat

Semarang
: Jl. Bumi Rejo 7b Tegal Rejo Argomulyo

\section{: TK Islam Tarbiyatul Banin 22}

: Tingkir Lor, Salatiga

: KB-TK Islam Sultan Al-Fattah

: Jalan Diponegoro 115 Salatiga

: TK IT Tarbiyatul Banin II

: Jl. Karang Taruna RT V/ RW VII Turusan

\section{: TK Kartika IX-25}

: Veteran Asrama Yonif 411

: TK Islam Tarbiyatul Banin 45

: Ngawen, Mangunsari, Salatiga

\section{: RA Miftahul Huda 01}

: Lopait RT.04 RW.01 Kec. Tuntang, Kab.

\section{Pembahasan}

\section{Hakekat Pendidikan Anak Usia Dini}

PAUD pada hakekatnya adalah pendidikan yang diselenggarakan dengan tujuan untuk memfasilitasi pertumbuhan dan perkembangan anak secara menyeluruh atau menekankan pada pengembangan seluruh aspek kepribadian anak.Oleh karena itu, upaya-upaya pengembangan anak usia dini hendaknya dilakukan melalui belajar dan melalui bermain (learning through games). Hal ini karena bermain merupakan kegiatan yang 
menyenangkan bagi anak. Melalui bermain anak memperoleh kesempatan untuk bereksplorasi (exploration), menemukan (finding), mengekspresikan (expression), perasaannya dan berkreasi (creation).

Banyak batasan yang diberikan terhadap program PAUD, namun sebelum membahas tentang hubungannya dengan pendidikan pada kesempatan ini perlu kita ketahui makna daripada anak usia dini. Menurut Mansur (2007: 87) anak usia dini adalah kelompok manusia yang berusia 0-6 tahun (UU no.20 tahun 2003 tentang Sistem Pendidikan Nasional). Selain hal tersebut turut dipaparkan mengenai anak usia dini adalah kelompok anak yang berada dalam proses pertumbuhan dan perkembangan koordinasi motorik halus dan kasar), intelegensi (daya pikir, daya cipta, kecerdasan emosi dan kecerdasan spiritual), sosial emosional (sikap dan perilaku serta agama), bahasa dan komunikasi yang khusus sesuai dengan tingkat pertumbuhan dan perkembangan anak.

Setelah kita mengetahui makna anak usia dini, berikut dipaparkan beberapa pengertian tentang PAUD, dalam hal ini UU No. 20 Tahun 2003 tentang Sistem Pendidikan Nasional mendefinisikan PAUD sebagai suatu upaya pembinaan yang ditujukan kepada anak sejak lahir sampai dengan usia enam tahun yang dilakukan melalui pemberian rangsangan pendidikan untuk membantu pertumbuhan dan perkembangan jasmani dan rohani agar anak memiliki kesiapan dalam memasuki pendidikan lebih lanjut. Menurut UU Sistem Pendidikan Nasional PAUD adalah suatu upaya pembinaan yang ditujukan kepada anak sejak lahir sampai dengan usia enam tahun yang dilakukan melalui pemberian rangsangan pendidikan untuk membantu pertumbuhan dan perkembangan jasmani 
dan rohani agar anak memiliki kesiapan dalam memasuki pendidikan lebih lanjut. (UUSPN, 2003:Pasal 1 ayat 14)

Dalam hal ini M. Hariwijaya (2007:14), mengemukakan bahwa PAUD dapat diartikan sebagai salah satu bentuk jalur pendidikan dari usia 0-6 tahun, yang diselenggarakan secara terpadu dalam satu program pembelajaran agar anak dapat mengembangkan segala guna dan kreativitasnya sesuai dengan karakteristik perkembangannya.

Menurut Bambang Hartoyo dalam Mansur (2007:89), mendeskripsikan makna PAUD sebagai berikut: pertama, PAUD adalah pemberian upaya untuk menstimulasi, membimbing, mengasuh dan pemberian kegiatan pembelajaran yang akan menghasilkan kemampuan dan keerampilan pada anak. Kedua, PAUD merupakan salah satu bentuk pelayananpenyelenggaraan pendidikan yang menitik beratkan pada peletakan dasar-dasar kearah pertumbuhan dan perkembangan fisik (koordinasi motorik halus dan kasar), kecerdasan (daya pikir, daya cipta, kecerdasan emosi dan keserdasan spiritual), sosio-emosional (sikap dan perilaku serta agama), bahasa dan komunikasi. Ketiga, sesuai dengan keunikan dan pertumbuhan PAUD disesuaikan dengan tahap-tahap pertumbuhan dan perkembangan yang dilalui oleh anak usia dini.

\section{TujuanPAUD}

Dari beberapa pengertian di atas, maka dapat ditarik kesimpulan bahwa tujuan PAUD adalah (a) Merangsang dan membantu pertumbuhan dan perkembangan jasmani dan rohani agar anak memiliki kesiapan dalam memasuki pendidikan lebih lanjut, (b)Mengembangkan segala 
potensi dan kreativitas anak sesuai dengan karakteristik perkembangannya agar mampu menyesuaikan diri dengan lingkungannya, dan (c) Menurut Hasentab dan Horner dalam Mansur (2007:93) mengemukakan bahwa salah satu tujuan dari pendidikan anak usia dini adalah memberikan pengalaman dan kesempatan yang akan membantu penguasaan kemampuan pada semua bidang perkembangan untuk meningkatkan kesempatan keberhasilan ketika anak memasuki jenjang pendidikan formal selanjutnya.

Dengan demikian jelas bahwa pendidikan anak usia dini adalah membekali dan menyiapkan anak sejak dini untuk memperoleh kesempatan dan pengalaman yang dapat membantu perkembangan kehidupan selanjutnya.

\section{Prinsip-prinsip PAUD}

Dalam mengembangkan PAUD terdapat prinsip-prinsip yang harus diperhatikan, antara lain:

1. Berorientasi pada perkembangan anak

2. Berorientasi pada kebutuhan anak (children oriented)

3. Merangsang potensi anak, aktif, kreatif, inovatif, efektifdan menyenangkan

4. Belajar melalui bermain

5. Menciptakan lingkungan yang kondusif

6. Berpusat pada anak

7. Pembelajaran terpaduantara tema yang menarik, minat anak dan kontekstual 
8. Dilaksanakan secara bertahap, berulang-ulang dan terus menerus

9. Mengembangkan berbagai kecakapan hidup (life skills)

10. Menggunakan berbagai media edukatif dan sumber belajar

11. Pemanfaatan teknologi informasi

\section{Bentuk-bentuk Satuan PAUD}

Dalam pelaksanaanya PAUD terbagi menjadi beberapa kategori sesuai jenjang Usia dan kelembagaan. Berdasarkan UU RI No. 20 tahun 2003 tentang Sistem Pendidikan Nasional pada pasal 28 tentang PAUD. Pada ayat 3 menyebutkan bahwa PAUD pada jalur pendidikan formal berbentuk Taman Kanak-kanak (TK), Raudatul Athfal (RA), atau bentuk lain yang sederajat.

Sedangkan pada ayat 4 menyebutkan bahwa PAUD pada jalur pendidikan formal dan non formal meliputi:

\section{Satuan PAUD pada Jalur Non-formal}

a. Kelompok Bermain (KB)

KB merupakan satu bentuk PAUD pada jalur non formal yang menyelenggarakan program pendidikan sekaligus program kesejahteraan bagi anak usia 2-4 tahun dan anak usia 4-6 tahun yang tidak dapat dilayani TK (setelah melalui pengkajian dan mendapat rekomendasi dari pihak berwenang).

b. Taman Penitipan Anak (TPA)

Taman Penitipan Anak adalah Salah satu bentuk PAUD pada jalur pendidikan non formal yang menyelenggarakan program kesejahteraan sosial, perawatan, pengasuhan, dan pendidikan 
sejak lahir sampai dengan usia 6 tahun. Taman Pendidikan Anak adalah layanan yang dilakasanakan oleh pemerintah dan masyarakat bagi anak usia 0-6 tahun yang orang tuanya bekerja.

c. Satuan PAUD Sederajat/ Satuan PAUD Sejenis (SPS)

Satuan PAUD sejenis (SPS) adalah merupakan layanan minimal yang hanya dilakukan 1-2 kali /minggu atau merupakan layanan PAUD yang dintegrasikan dengan program layanan lainnya. Peserta program PAUD sejenis adalah anak usia 2-4 tahun. Beberapa bentuk Pendidikan Anak Usia Dini pada jalur pendidikan non formal selain Taman Penitipan Anak dan Kelompok Bermain, yaitu:

1) Pos Pendidikan Anak Usia Dini (Pos PAUD)

Pos PAUD adalah salah satu bentuk satuan PAUD pada jalur pendidikan nonformal yang menyelenggarakan program pendidikan dan pengasuhan bagi anak sejak lahir sampai dengan berusia 6 (enam) tahun yang penyelenggaraannya dapat diintegrasikan dengan program Bina Keluarga Balita (BKB) dan/atau Pos Pelayanan Terpadu (Posyandu).

2) Pendidikan Anak Usia Dini Berbasis TPQ (PAUD TPQ)

PAUD Berbasis TPQ adalah bentuk bentuk pendidikan anak usia dini pada jalur pendidikan nonformal yang dilaksanakan secara terintegrasi dengan Taman Pendidikan al-Qur'an. Lembaga ini lahir atas dasar dorongan tumbuhnya kesadaran dan gerakan pendidikan berbasis al-Qur'an, terutama dalam 
bentuk TKA/TPA/TQA yang dimotori BADKO TPQ, BKPRMI, Muslimat, Aisiyah dan sejenisnya. PAUD berbasis TPQ tidak dimaksudkan untuk menggantikan program pendidikan al-Qur'an melainkan untuk memperkuat dan melengkapinya dengan substansi PAUD. (Juknis Penyelenggaraan PAUD TPQ Kemendikbud, 2011:2) .

3) Taman Asuh Anak Muslim (TAAM)

Taman Asuh Anak Muslim (TAAM) adalah salah satu bentuk satuan PAUD pada jalur pendidikan nonformal yang menyelenggarakan program pendidikan dan pengasuhan bagi anak berusia 2 (dua) tahun sampai dengan 6 (enam) tahun yang berbasis Taman Pendidikan Al-Quran.

4) Pendidikan Anak Usia Dini Sekolah Minggu (PAUD-SM) Pendidikan Anak Usia Dini Sekolah Minggu (PAUD-SM) adalah salah satu bentuk satuan PAUD pada jalur pendidikan nonformal yang menyelenggarakan program pendidikan keagamaan Kristen bagi anak berusia 2 (dua) tahun sampai dengan 6 (enam) tahun berbasis Sekolah Minggu.

5) Pendidikan Anak Usia Dini Bina Iman Anak (PAUD-BIA) Pendidikan Anak Usia Dini Bina Iman Anak (PAUD-BIA) adalah salah satu bentuk satuan PAUD pada jalur pendidikan nonformal yang menyelenggarakan program pendidikan keagamaan Katholik bagi anak berusia 2 (dua) tahun sampai dengan 6 (enam) tahun yang berbasis Bina Iman Anak Katolik. 


\section{Satuan PAUD pada Jalur Formal}

a. Taman Kanak-Kanak

Taman Kanak-Kanak yaitu bentuk satuan PAUD pada jalur pendidikan formal yang menyelenggarakan program pendidikan bagi anak usia 4-6 tahun, yang dibagi menjadi dua kelompok, yakni kelompok A untuk anak usia 4-5 tahun dan kelompok B untuk anak usia 5-6 tahun

b. Raudhatul Athfal

Taman Kanak-Kanakyaitu salah satu bentuk satuan PAUD pada jalur pendidikan formal yang menyelenggarakan program pendidikan umum dan pendidikan keagamaan Islam bagi anak usia 4 sampai 6 tahun

c. Satuan Pendidikan Anak Usia Dini jalur Formal yang Sederajat Salah satu bentuk PAUD pada jalur pendidikan formal selain Taman kanak-kanak dan Raudatul Athfal, yaitu: Tarbiyatul Athfal (TA), Taman Kanak-kanak al-Qur'an (TKQ), dan Taman Pendidikan al-Qur'an (TPQ).

\section{Landasan Hukum (Yuridis)PAUD}

Dijelaskan oleh M. Hariwijaya dan Bertiani ES, 2007:20-21 dalam http://anisachoeriah-paud.blogspot.com, bahwasanya Penyelenggaraan program PAUD di Indonesia mengacu pada aturan dan kebijakan yang dikeluarkan pemerintah sebagai berikut:

a. UUD 1945 pasal 28 ayat 2

b. UU. No. 4 Tahun 1974 mengenai Kesejahteraan Anak 
c. UU. No. 23 Tahun 2002 mengenai Perlindungan Anak

d. UU. No. 20 Tahun 2003 mengenai Sistem Pendidikan Nasional.

e. PP. No. 19 Tahun 2005 mengenai Standar Pendidikan Nasional

f. Peraturan Presiden Republik Indonesia No. 7 Tahun 2005 mengenai Rencana Pembangunan Jangka Menengah Tahun 2004-2009.

g. Keputusan Menteri Pendidikan Nasional nomor 13 Tahun 2005 tentang Organisasi dan Tata Kerja Direktorat Jenderal Pendidikan Luar Sekolah, Departemen Pendidikan Nasional.

h. Rencana strategis Departemen Pendidikan Nasional Tahun 20052009.

\section{Landasan Filosofis PAUD}

Anak usia dini, yakni anak dengan usia pra-sekolah (0-6 tahun) berdasarkan berbagai penelitian merupakan masa keemasan manusia (golden age), dimana kecerdasan manusia ditentukan pada masa-masa ini (Hariwijaya, 2007:32). Dengan adanya pendidikan anak usia dini diharapkan anak dapat tumbuh dengan segala potensinya, sehingga ia mampu membangun dirinya, lingkungan dan bangsanya.

\section{Standar Kompetensi Anak Usia Dini}

PAUD dalam pengembangan aspek-aspek pembelajarannya harus mengacu pada standar kompetensi anak usia dini yaitu Moral dan Nilainilai Agama, Sosial dan Emosional, Fisik/ Motorik, Bahasa, Kognitif, danSeni. 


\section{Prinsip-prinsip Dasar Kurikulum PAUD}

Kurikulum PAUD adalah kurikulum operasional yang disusun dan dilaksanakan oleh masing-masing Lembaga baik PAUD formal atau Kurikulum pada jenjang PAUD yang mengacu pada Permendiknas No.58 Tahun 2009 dan berpedoman pada panduan penyusunan KTSP dari Badan Standar Nasional Pendidikan.

Direktorat PAUD menetapkan beberapa prinsip dasar kurikulum PAUD, yang meliputi: 1) bersifat komprehensif, 2) didasarkan pada perkembangan secara bertahap, 3) melibatkan orang tua, 4) melayani kebutuhan anak, 5) merefleksikan kebutuhan dan nilai-nilai yang dalam masyarakat, 6) mengembangkan standar kompetensi anak, 7) mewadahi layanan anak berkebutuhan khusus, 8) menjalin kemitraan dengan keluarga dan masyarakat, 9) memperhatikan kesehatan dan keselamatan anak, 10) menjabarkan prosedur pengelolaan lembaga, 11) manajemen sumber daya manusia, dan 12) penyediaan sarana dan prasarana.

\section{Komponen Kurikulum PAUD}

a. Anak, sasaran PAUD adalah anak yang berada di rentang usia 0-6 tahun

b. Pendidik, kompetensi pendidik PAUD adalah sekurang-kurangnya memiliki kualifikasi akademik Diploma Empat (D-IV) atau Sarjana (S-1) di bidang pendidikan usia dini, psikologi atau lainnya; dan memiliki sertifikat profesi guru PAUD.

c. Pembelajaran, materi pembelajaran bagi anak usia dini dibagi dalam 2 kelompok usia, yaitu: 
1) Materi Pembelajaran Untuk Anak usia 0-3 tahun, mencakup Pengenalan diri sendiri (perkembangan konsep diri), Pengenalan perasaan (perkembangan emosi), Pengenalan tentang orang lain (perkembangan sosial), Pengenalan berbagai gerak (Perkembangan fisik), Mengembangkan komunikasi (perkembangan bahasa), dan Keterampilan berfikir (perkembangan kognitif).

2) Materi Pembelajaran untuk anak usia 3-6 tahun, mencakup:

a) Keaksaraan, yaitu meliputi pengenalan terhadap kosakata dan bahasa, kesadaran phonologi, percakapan, memahami buku, dan teks lainnya.

b) Konsep matematika, mencakup pengenalan angka-angka, pola-pola dan hubungan, geomteri dan konsep matematika lainnya.

c) Pengetahuan alam, yang mencakup pengenalan terhadap objek fisik, kehidupan, bumi dan lingkungan.

d) Pengetahuan sosial, meliputi kehidupan orang banyak, bekerja, interaksi sosial, lingkungan rumah dan keluarga, dan lainnya.

e) Seni, mencakup kegiatan menari, menyanyi, bermain peran, bermain musik, menggambar dan melukis.

f) Teknologi, dengan mengenalkan alat-alat dan penggunaan operasi dasar dan kesadaran teknologi. Alat-alat yang dikenalkan di mulai dari alat-alat yang ada rumah, seklah, dan lingkungan tempat anak tinggal. 
g) Keterampilan proses, mencakup pengamatan dan eksplorasi; eksperimen; pemecahan masalah; koneksi, pengorganisasian, komunikasi dan informasi yang mewakilinya.

d. Pengelolaan Pembelajaran

Dalam mengelola pembelajaran, PAUD harus memperhatikan aspekaspek sebagai berikut Keterlibatan anak danLayanan program.

e. Melibatkan peran serta masyarakat

\section{Pendidikan Agama Islam pada Anak Usia Dini}

Kaitannya dengan pendidikan agama, para ahli menjelaskan diantaranya dijelaskan dalam Encyclopedia Education sebagaimana kutipan Zuhairini dkk (1993:10) Pendidikan agama adalah suatu kegiatan yang bertujuan untuk menghasilkan orang beragama. Dengan demikian perlu diarahkan kepada pertumbuhan moral dan karakter. Pendidikan Agama tidak cukup hanya memberikan pengetahuan tentang agama saja, akan tetapi disamping Pendidikan Agama, mestilah ditekankan pada feeling attituted, personal ideal, aktivitas, dan kepercayaan.

Zuhairini dkk, menjelaskan bahwa Pendidikan Agama berarti usahausaha secara sistematis dan pragmatis dalam membantu anak didik agar supaya mereka hidup sesuai dengan ajaran Islam"(1983:27). Pendidikan Agama sebagai usaha membimbing dan mengasuh anak didik untuk dapat memahami dan mengamalkan ajaran-ajaran agama Islam, serta menjadikannya sebagai way oflife (jalan kehidupan).

Secara lebih rinci dijelaskan oleh Nur Uhbiati dalam bukunya Ilmu Pendidikan Islam, (1997: 50) bahwasanya pendidikan agama Islam 
memiliki tujuan yang lebih luas cakupannya yaitu: (1) Untuk membantu terbentuknya akhlak yang mulia, (2) Mempersiapkan untuk mencari rizki dan kehidupan akhirat, (3) Persiapan untuk mencari rizki dan pemeliharaan segi-segi kemanfaatan, (4) Menumbuhkan semangat ilmiah (scientific spirit) pada pelajar dan memuaskan keinginan dan memungkinkan ia mengkaji ilmu demi ilmu itu sendiri, dan (5) Menyiapkan pelajar dari segi professional atau keahlian tertentu, agar dapat mencari rizki dalam kehidupannya di samping juga memelihara segi kerohanian dan keagamaan.

Asasdasardalammateripendidikanagama sebagaimana yang disampaikan Muhaimin (2001:29) bahwasanyapendidikan agama islam adalah pendidikan yang dipahami dan dikembangkan dan ajaran dan nilai-nilai fundamental yang terkandung dalam sumber dasar-dasamya yaitu al-Qur'an dan Al-Sunnah.

Secara lebih sistematis materi pendidikan agama islam sebagaimana yang dijelaskan oleh Zuhairini (1999:61) memiliki tiga ajaran yang menjadi inti dasar dalam mengatur kehidupan. Secara umum dasar Islam yang dijadikan materi pokok pendidikan agama Islam dalam keluarga yaitu: masalah keimanan (Aqidah), Ibadah (Fiqih) danIhsan (Akhlak). Hal ini sebagai rambu-rambu penyusunan kurikulum pendidikan anak usia dini dalam aspek agama dan nilai moral.

\section{Metode Pendidikan Agama Islam pada Anak Usia Dini}

Guru memerlukan metode yang bervariasi untuk menciptakan iklim pembelajaran yang menyenangkan bagi anak. Menurut Jamal Ma'ruf 
Asmani (2009:100) "mengajar anak usia dini membutuhkan metode yang unik dan kreatif. Metode adalah "suatu cara dan siasat menyampaikan bahan pelajaran tertentu dari suatu mata pelajaran agar siswa dapat mengetahui, memahami mempergunakan atau dengan kata lain dapat menguasai bahan pelajaran tersebut" (Zuhairini,1983:79).Dari pengertian metode tersebut di atas dapat disimpulkan metode pendidikan agama adalah segala usaha yang sistematis dan pragmatis untuk mencapai tujuan pendidikan agama dengan berbagai aktifitas, baik di dalam atau di luar kelas dalam lingkungan sekolah.

Ada banyak metode atau cara yang digunakan untuk menyampaikan materi pendidikan agama Islam pada anak usia dini, sebagaimana menurut Winarno suradi yang dikutip oleh Zuhairini (1983:82) diantaranya: (1) Metode ceramah, (2) Metode tanya jawab, (3) Metode pemberian tugas, (4)Metode demonstrasi da eksperimen, dan (5) Metode belajar kelompok, dll.

Selain metode diatas, ada beberapa metode yang digunakan dalam Pendidikan Agama Islam pada anak usia dini diantaranya: (1) Metode Keteladanan, (2) Metode Cerita atau Kisah, (3) Metode Nasehat,(4) Metode Pembiasaan, dan (5) Metode Ganjaran/Hadiah dan Hukuman(Reward and Punishment).

\section{Analisis Implementasi Kurikulum PAI pada Anak Usia Dini (6 tahun) di PAUD Kota Salatiga dan Kab. Semarang}

Pelaksanaan atau implementasi kurikulum PAIpada anak usia dini pada PAUD di Kota Salatiga dan Kab. Semarang berdasarkan kurikulum 
PAI dengan rumusan tentang materi, metode dan strategi pendidikan. Bahan-bahan pendidikan agama berupa kegiatan, pengetahuan dan pengalaman yang dengan sengaja dan sistematis, diberikan kepada anak didik dalam rangka mencapai tujuan pendidikan agama Islam.

Hasil penelitian menunjukkan bahwa sebagian besar PAUD yang ada di kota Salatiga menggunakan Kurikulum PAI dari Kementerian agama yang dipadukan dengan dasar dan rambu-rambu dari dinas Pendidikan Pemuda dan Olahraga. Kebanyakan setiap PAUD telah mengimplementasikan acuan dasar kurikulum PAUD sesuai dengan Permendiknas no 58 tahun 2009 dengan mulai berkreasi mengembangkannya sesuai dengan tingkat pertumbuhan dan perkembangan peserta didik dan kekhasan lembaga masing-masing. Akan tetapi masih ditemui beberapa PAUD yang belum mengacu pada Permendiknas no 58 tahun 2009 dan masih menggunakan kurikulum KBK dan acuan dari pihak yayasan, bahkan ada dalam pedoman pembelajarannya tidak menggunakan kurikulum tertulis secara resmi, guru hanya mengandalkan rambu-rambu yang diberikan oleh pihak Yayasan sebagai acuan dasar pembelajaran yang diajarkan dalam nilai moral dan religius seperti contohnya doa sehari- hari, surat- surat pendek, nama-nama malaikat, rukun iman dan rukun islam. Dalam proses pembelajarannya hanya menggunakan pengalaman- pengalaman dari seorang guru.

Implementasi kurikulum pendidikan agama Islam di PAUD Kota Salatiga dan Kab. Semarang terlihat dari proses kegiatan di sekolah, mulai dari awal masuk sampai pulang sekolah materi agama Islam 
diterapkan, dibiasakan dan dilatih kepada peserta didik, seperti mengucapkan salam kepada guru, menjaga kerapian dan kebersihan lingkungan sekolah, bacaan al-Qur'an dan pembiasaan shalat. Materi agama Islam yang di ajarkan meliputi mengucapkan dengan fasih dua kalimat syahadat, kalimat Thayyibah, tatacara berwudlu, bacaan sholat termasuk azan dan iqomah, puasa, berzakat, nama-nama malaikat dan tugasnya masing-masing, mengenal Nabi dan sifatnya, beberapa surat pendek dalam al-Qur'an, doa harian, mengenal huruf hijaiyah, kehidupan akhirat dan takdir Allah, melaksanakan hari besar Islam, memperagakan manasik haji secara sederhana.

Implementasi kurikulum PAI pada anak usia dini yang ada pada PAUD kota Salatiga dan Kab. Semarang meski ada beberapa materi yang kurang sesuai dengan standar yang ada, Menurut peneliti dirasa sudah baik karena dilihat dari prosentase siswa cukup banyak dan juga mendapat kepercayaan dari masyarakat untuk mendidik anak-anak mereka sehingga tiap tahun ajaran baru murid selalu bertambah. Selain itu kegiatan pendidikan yang ada di sekolah mulai awal masuk hingga pulang sekolah masih menerapkan pendidikan agama, serta srategi dan pendekatan pembelajaran yang diterapkan berorientasi pada karakteristik Permendiknas No 58 tahun 2009.

\section{Analisis Metode dan Strategi Implementas iPendidikan Agama Islam pada PAUD Kota Salatigadan Sekitarnya}

Dari beberapa PAUD yang ada dalam mengimplementasikan nilainilai keagamaan menggunakan strategi pembelajaran diantaranya 
keteladanan, pembiasaan/latihan, syair, penciptaan suasana religius, bercerita dll. pembelajaran sesuai tema berbasis sentra / BCCT (Beyond Centers and Circle Time). Sesuai karakter lembaga masing-masing tiap kelas dibuat sebuah centra yang terdiri dari Sentra Ibadah, Sentra Bahan Alam, Sentra Seni dan Kreativitas, Sentra Persiapan, Sentra Balok dan Sentra Komputer.Ditambah dengan Belajar Kelompok. Kesemua strategi dan metode diterapkan dengan Berpusat pada Anak.

Dengan adanya kurikulum yang dipakai sebagai acuan pembelajaran, sangat memungkinkan dibutuhkannya strategi dan metode yang jelas untuk pengimplementasian kurikulum tersebut kepada peserta didik khususnya dalam kaitannya dengan pendidikan agama Islam, didapatkan berbagai strategi yang diterapkan oleh beberapa PAUD di kota salatiga dalam pelaksanaanya menggunakan multi strategi diantaranya: (1) Pembelajaran berpusat pada anak, (2) Penciptaan suasana religius, (3) Keteladanan, (4) Pembiasaan dan latihan, (5) Permainan, (6) Cerita, (7) Nyanyian, (8) Pemberian tugas, (9) Pembelajaran berbasis sentra/ BCCT (Beyond Centers and Circle Time).

Dalam penerapannya disesuaikan dengan materi yang akan diajarkan. Misalnya:

1. Strategi penciptaan suasana religius diterapkan dalam materi ucapan-ucapan tauhid/kalimah thoyyibah, mengajari anak untuk untuk berwudhu dan sholat, membaca,menghafal surat-surat pendek.

2. Strategi pembiasaan diterapkan dengan setiap hari jum'at semua siswa diajarkan praktik shalat. 
3. Strategi nyanyian diterapkan didalam pengenalan-pengenalan namanama Nabi, Malaikat, Surga dan Neraka, dll.

4. Strategi berceritera dipakai untuk mengajarkan kisah-kisah nabi, sifat-sifatnya disertai guru menjadi teladan dalam mengajarkan sikap-sikap Nabi.

5. Strategi pemberian tugas biasanya lebih kepada nasihat, misalnya mengucapkan salam dan berjabat tangan dengan orang tua.

6. Adapun lebih jelasnya materi PAI Serta Strategi dan Metode Pengajaran yang diterapkan sebagaimana dibawah ini:

\begin{tabular}{|l|l|l|}
\hline No & \multicolumn{1}{|c|}{ Materi PAI } & \multicolumn{1}{c|}{ Strategi } \\
\hline 1 & Doa-doa sehari-hari, surat-surat pendek & $\begin{array}{l}\text { Pembiasaan sebelum dan sesudah } \\
\text { mulai pembelajaran }\end{array}$ \\
\hline 2 & Ucapan- ucapan Tauhid/ Kalimah toyibah & Bernyanyi dan tepuk tangan \\
\hline 3 & $\begin{array}{l}\text { Pengenalan nama-nama Nabi dan } \\
\text { Malaikat }\end{array}$ & $\begin{array}{l}\text { Bercerita tentang sejarah } \\
\text { nabidengan ekspresi. }\end{array}$ \\
\hline 4 & Asmaul Husna & $\begin{array}{l}\text { Mengucap bersama-sama dengan } \\
\text { nada/lagu }\end{array}$ \\
\hline 5 & Iqra' atau hafalan surah pendek & Pembiasaan \\
\hline 6 & Akidah Akhlak & $\begin{array}{l}\text { Memberikan contoh sehari-hari, } \\
\text { serta berbicara yang sopan, dan } \\
\text { baik }\end{array}$ \\
\hline 7 & Ibadah Sholat & $\begin{array}{l}\text { Mengadakan praktik sholat } \\
\text { jamaah setiap hari, Sholat Dhuha }\end{array}$ \\
\hline
\end{tabular}

Untuk menciptakan suasana yang tidak membosankan, di sela-sela proses belajar, anak-anak diajari menyanyi lagu baru oleh guru. Strategi dan metode kami padukan menyesuaikan dengan situasi dan kondisi peserta didik, dan menggunakan pendekatan yang berbasis pada anak. Dalam proses pelaksanaanya kami berusaha menciptakan model pembelajaran Paikem Gembrot yaitu pembelajaran yang aktif, inovatif, kreatif, efektif, menyenangkan, gembira dan berbobot." 
Berkaitan dengan pelaksanaan pendidikan agama Islam, dalam prosesnya banyak menggunakan metode yang dapat menarik perhatian ana didik, Pemberian tugas, Karya wisata, Bermain Peran Macro dengan praktek langsung. Micro dengan menggunakan APE, Demonstrasi, metode tanya jawab, bernyanyi dan bertepuk, ceramah, bercerita, eksperimen, study lingkungan, syair, flashcard (bahasa Indonesia, inggris dan arab) dll. Observasi, Sharring. Penugasan. Hasil karya dan unjuk kerja. Pemberian keterampilan dengan cara menugaskan siswa membuat prakarya seperti menggambar bebas dan membut tempat sampah. Metode Karyawisata, Metode Bermain Drama.

Dengan metode yang bermacam-macam tersebut diharapkan akan meningkatkan kemampuan dan daya tangkap ana didik serta tujuan pembelajaran yang diharapkan akan tercapai. Dengan banyaknyametode diharapkan guru mampu memilih mana yang paling tepat untuk materi yang akan disampaikan sehingga anak tidak terkesan bosan dan akanselalutertarik untuk mengikuti pembelajaran.

\section{Kesimpulan}

Dari objek penelitian didapatkan sebuah pemahaman tentang bagaimana kurikulum diimplementasikan. Untuk kurikulum secara umum hampir setiap PAUD telah mengacuan pada dasar kurikulum PAUD sesuai dengan Permendiknas no 58 tahun 2009 dengan mulai berkreasi mengembangkannya sesuai dengan tingkat pertumbuhan dan perkembangan peserta didik masing-masing lembaga masing-masing meskipun masih ada beberapa PAUD yang belum tahu atau belum 
mengacu pada Permendiknas no 58 tahun 2009, bahkan masih menggunakan acuan kurikulum KBK dan acuan dari pihak yayasan.

Kaitannya dengan Kurikulum PAI mayoritas PAUD mennggabungkan antara kurikulu Dinas pendidikan dan kementerian agama, selain itu guru menggunakan rambu-rambu yang diberikan oleh pihak Yayasan sebagai acuan dasar pembelajaran yang diajarkan dalam nilai moral dan religius diantaranya doa sehari- hari, surat- surat pendek, nama-nama malaikat, rukun iman dan rukun islam. Dalam proses pembelajarannya hanya menggunakan pengalaman- pengalaman dari seorang guru.

Implementasi kurikulum pendidikan agama Islam di PAUD Kota Salatiga dan Kab. Semarang ditunjukkan dari proses kegiatan di sekolah, mulai dari awal masuk sampai pulang sekolah materi agama Islam diterapkan, dibiasakan dan dilatih kepada peserta didik, seperti mengucapkan salam kepada guru, menjaga kerapian dan kebersihan lingkungan sekolah. Materi agama Islam yang di ajarkan meliputi mengucapkan dengan fasih dua kalimat syahadat, kalimat Thayyibah, tatacara berwudlu, bacaan sholat termasuk azan dan iqomah, puasa, berzakat, nama-nama malaikat dan tugasnya masing-masing, mengenal Nabi dan sifatnya, beberapa surat pendek dalam al-Qur'an, doa harian, mengenal huruf hijaiyah, kehidupan akhirat dan takdir Allah, melaksanakan hari besar Islam, memperagakan manasik haji secara sederhana.

Metode yang paling banyak digunakan dalam memberikan materi PAI adalah Demonstrasi, pemberian tugas, bermain peran, bercerita, 
iqro', simulasi dan karya studi. Sedangkan metode studi lingkungan dilakukan menyesuaikan dengan kondisi dan tema pembelajaran, seperti contoh: Saat tema masjidku, anak-anak diajak studi lingkungan objek tertentu. Tema sedekah anak diajak ke panti asuhan untuk belajar berbagi bersama. dengan metode dan strategi tersebut anak akan lebih mampu dan mudah dalam menerima materi sehingga kedepan tujuan pendidikan aanak usia dini akan tercapai.

\section{Daftar Pustaka}

Asnelly Ilyas. 1995. Mendambakan Anak Saleh. Bandung: Al-Bayan.

Departemen Pendidikan dan Kebudayaan. 2007. Undang-undang No.20 Tahun 2009 Tentang Sistem Pendidikan Nasional. Depdiknas:Jakarta.

Direktorat Pendidikan Anak Usia Dini, Depdiknas. 2007. Kerangka Dasar Kurikulum Pendidikan Anak Usia Dini. Universitas Negeri Jakarta: Jakarta.

Hariwijaya, M. dan Bertiani Eka Sukaca. 2007. PAUD Melejitkan Potensi Anak dengan Pendidikan Sejak Dini. Bandung:

Kemendiknas. 2011. Petunjuk Teknis Penyelenggaraan Taman KanakKanak.

Mansur. 2007. Pendidikan Anak Usia Dini dalam Islam. Yogyakarta: Pustaka Pelajar. cet.ke 2.

2009. Pendidikan Anak Usia Dini dalam Islam. Pustaka Pelajar:Yogyakarta. cet.ke-3.

Moleong, Lexy J. 2005. Metodologi Penelitian Kualitatif, Bandung: Remaja Rosdakarya.

Muhaimin, 2001. Paradigma Pendidikan Islam: Upava Mengefektifkan Pendidikan Agama Islam di Sekolah. Bandung: Rosda Karya. 2003. Wacana Pengembangan Pendidikan Islam. Yogyakarta:

Pustaka Pelajar.

. 2004.Pengembangan Kurikulum Pendidikan Agama Islam. Jakarta: Raja Grafindo.

Nur Uhbiati. 1997..Ilmu Pendidikan Islam. Bandung: Pustaka Setia. 
Permendiknas No 58 tahun 2009 Tentang Standar Pendidikan Anak Usia Dini.

Tim Dosen IAIN Malang. 1996. Dasar-Dasar Pendidikan Islam: Suatu Pengantar Ilmu Pendidikan Islam. Surabaya: Karya Aditama.

Zuhairini. 1983. Methodik Khusus Pendidikan Agama. Malang: Biro llmiah Fakultas Tarbiyah. dkk. 1993, Metodologi Pendidikan Agama. Solo: Ramadhani. 